\title{
ANALISIS METODE HILAH DALAM PROSES FATWA DSN-MUI
}

\author{
Elimartati \\ Fakultas Syariah IAIN Batusangkar \\ Jl. Sudirman No. 137 Kuburajo Lima Kaum Batusangkar \\ e-mail: elimartati2013@gmail
}

\begin{abstract}
This study focused on the implementation of hilah method within the concept of fatawa of DSN concerning with Sharia banking product agreement. The problems of the research was formulated as follows: "Does DSN determine the fatawa concerning with Sharia banking product agreement apply the concept of hilab?" This study belonged to library research which studied documents of fatawa of $D S N$. The method employed was normative qualitative using content analisys using the rules of istimbat. The study began with figuring out the position of bilah method in Islamic laws. Next, gathering and analyzing the fatawa of DSN concerning with Sharia banking product. The finding showed that the process of determination of some fatawa applied bilab method by modifying the format of fikith muamalah. Most of the determination of fatawa of DSN used bilah methods for the goode sake consideration.
\end{abstract}

Kata kunci: hilah, fatwa DSN-MUI, akad

\section{PENDAHULUAN}

$P$ emicu fatwa ada yang disebabkan perubahan yang dialami oleh masyarakat, baik perubahan pola hidup atau karena perkembangan teknologi. Fatwa yang merupakan pendapat ulama bertujuan untuk menyelesaikan masalah-masalah hukum yang dihadapi masyarakat. Oleh karena itu fatwa bersifat domestik, situsional, dan temporal. Hal ini didukung oleh kaedah fikih yang dikemukakan oleh Ibnu Qayyim alJauziyah sebagai berikut :

$$
\begin{aligned}
& \text { تغير الفتوى واختلافها بحسب تغير ا لأزمنة وا لأمكنة } \\
& \text { والأحوال والنيات والعوائد }
\end{aligned}
$$

Berubah dan berbedanya fatwa sesuai dengan perubahan zaman, tempat, kondisi sosial, niat, dan adat kebiasaan. (Ibnu Qayyim al-Jauziyyah, 1975: 4)
Mengaplikasikan sejumlah konsep fikih muamalah sebagai sumber sistem ekonomi syariah di Indonesia, terutama dalam produk perbankan syariah DSNMUI mengeluarkan beberapa fatwa sesuai dengan jenis produk yang dibutuhkan. Proses penetapan fatwa mengikuti metode ijtihad, karena metode fatwa hampir sama dengan berijtihad yakni mengeluarkan hukum dan menetapkan hukum tentang sesuatu masalah yang tengah dibutuhkan masyarakat.

Mujtahid mengistinbatkan hukum, mulai dengan menggali ayat- ayat dalam Alquran sebagai sumber hukum utama dan juga merujuk Hadis Rasulullah Saw. Menelaah maksud yang terkandung dalam Alquran maupun Hadis, ulama mengunakan akal pikiran sehingga melahirkan metode-metode baru dalam penetapan hukum suatu masalah. Langkah penetapan hukum tersebut 
dilakukan dengan menggali hukum sehingga melahirkan hukum-hukum dalam masalah yang dibutuhkan oleh masyarakat untuk kemaslahatan manusia.

Dewan Syariah Nasional dalam merumuskan bentuk-bentuk kegiatan keuangan yang Islami terlihat menempuh dua cara yang saling berkaitan sebagai berikut; Pertama, menerapkan ketentuan ketentuan yang terdapat dalam fikih muamalah dalam format yang sesuai dengan praktek kegiatan keuangan yang berlaku. Praktek bank syariah yang ada saat ini dengan fungsi menghimpun dana dari umat yang berkelebihan dana dan menyalurkannya kepada yang memerlukan, kebanyakannya adalah penerapan dari fikih muamalah. Kedua, Islamisasi kegiatan dan produk perbankan yang konvensional dengan cara menghilangkan unsur-unsur yang dilarang agama, menggantinya dengan praktek yang tidak dilarang agama, (Amir Syarifuddin, 2009: 3-4). Fatwa DSN dalam penetapan akad-akad produk perbankan syariah diperkirakan terjadi modifikasi fikih muamalah dalam prosesnya. Fatwa DSN dalam memproses penetapan fatwa apakah dapat dikatakan memakai metode hilah dengan cara memodifikasi dan mengakali format fikih muamalah. Manakala DSN memakai hilah dalam menetapkan fatwanya, apakah hilah-nya dapat dibenarkan dalam hukum Islam atau tidak?. Menjawab permasalahan di atas perlu dikaji dan diteliti secara seksama.

\section{METODE PENELITIAN}

Penelitian merupakan pranata sosial yang berkaitan dengan Fatwa DSN. Jenis penelitian book survei (library research). Pendekatan yang dipakai kualitatif normatif, dengan melakukan penelitian bersifat conten analisis dalam proses istinbat hukum yang bersumber dari fatwa DSN tentang akad produk-produk perbankan syariah menerapkan konsep hilah. Penelitian diawali dengan melihat kedudukan metode hilah dalam hukum Islam. Selanjutnya menginventarisasi Fatwa DSN tentang produk perbankan syariah, kemudian menelaah dalil-dalil hukum yang dipakai dalam fatwa berupa ayat-ayat Alquran, yakni menginventaris ayat-ayat yang menjadi dalil hukum dan manafsirkannya dengan berlandaskan pendapat para mufasir. Kemudian menginventaris Hadis-hadis Rasulullah Saw yang menjadi dasar hukum dari masalah yang ditetapkan hukumnya. Mengambil kaedah hukum yang menjadi dalil pelengkap dari dalil-dalil di atas. Dalam hal yang belum jelas hukumnya ditetapkan berdasarkan dalil di atas, maka melihat dalil- dalil hukum yang dipakai para ulama dalam mengistinbatkan hukum, dan melihat penerapan metode hilah dalam istinbatnya. Penelitian ini menganalisis penerapan hilah dalam penetapan fatwa DSN tentang akad-akad produk perbankan syariah. Karena keterbatasan waktu, biaya dan kemampuan dalam penelitian ini. Fatwa yang diteliti berjumlah delapan sebagai berikut :

1. Fatwa Dewan Syariah Nasional Nomor: 22/DSN-MUI/III/2002 tentang Jual Beli Istishna' Paralel

2 Fatwa Dewan Syariah Nasional Nomor 27/DSN-MUI/III/ 2002 tentang al-ljarah alMuntahiyahbi al-Tamlik

3. Fatwa Dewan Syariah Nasional Nomor: 31/DSN-MUI/VI/2002 tentang Pengalihan Utang

4. Fatwa Dewan Syariah Nasional Nomor 42/DSN-MUI/ V/ 2004 tentang Syariah Char Card 
5. Fatwa Dewan Syariah Nasional Nomor 44/DSN-MUI/ VIII/ 2004 tentang Pembiayaan Multi Jasa

6. Fatwa Dewan Syariah Nasional No: 50/DSN-MUI/III/2006 tentang Akad Mudharabah Musytarakah

7. Fatwa Dewan Syariah Nasional Nomor 72/DSN-MUI/ VI/ 2008 tentang Surat Berharga Syariah Negara Ijarah Sale and Lease Back

8. Fatwa Dewan Syariah Nasional Nomor 73/DSN-MUI/XI/2008 tentang Musyarakah Mutanaqisah

Data tentang metode hilah diambil dari pendapat ulama bersumber dari buku-buku yang membahas tentang hilah diantaranya adalah buku al-Syatibi berjudul alMuwafaqat fi Ushul al- Syar'iyah, buku Ali Hasaballah berjudul Ushul al- Tasyri' al-Islami, buku Wahbah al-Zuhaili berjudul Ushul al- Fiqh al-Islami. Buku Ibnu Qyyim al-Jauziyah I'lam al-Muwaqi'in an Rabb al-'Alamin dan buku Muhammad Abu Zahra berjudul Ushul al- Figh.

Berdasarkan uraian di atas dapat dirumuskan pertanyaan penelitian" apakah penetapan Fatwa DSN tentang produk perbankan syariah menerapkan hilah syar'iyah. fokus penelitian yaitu: apakah metode penetapan fatwah DSN tentang akad produk-produk perbankan syariah memakai metode hilah, apakah penerapan hilah dalam penetapan produk-produk perbankan syariah dapat dibenarkan dalam hukum Islam.

\section{PEMBAHASAN}

\section{Pengertian Hilah dan Macam-Macam Hilah}

\section{Pengertian Hilah}

Hilah secara bahasa berarti kecerdikan, tipu daya, dan yang dicari untuk melepaskan diri dari suatu beban dan tanggung jawab (Abdul Aziz Dahlan, 2003: 553). Hilah secara defenitif di ungkapkan oleh para ulama diantaranya: Al- Syaitibi (1971: 558) mengemukakan pengertian hilah ialah upaya mendahulukan amalan yang zahir meskipun diperkenankan untuk membatalkan hukum syar'i dan merubahnya menjadi hukum yang lain. Dengan demikian dalam kenyataannya amalan tersebut cenderung untuk menciptakan kaidah-kaidah hukum Islam yang baru. Sedangkan Ibnu Qayyib al-Jauziyyah mengemukakan defenisi hilah dengan sebuah tindakan khusus yang menyebabkan pelakunya mengalami perubahan dari satu keadaan kepada keadaan yang lain, kemudian penggunaan kata tersebut berkembang menjadi istilah yang lebih khusus dengan mengalami penyempitan makna yakni kiat atau cara terselubung yang mengantarkan seseorang untuk mencapai tujuan dan maksudnya. Cara ini tidak ditemukan kecuali dengan kecakapan dan keahlian khusus. Dapat dipahami bahwa pelaku hilah dalam tindakannya mencoba merubah substansi hukum syara' kepada hukum yang lain, perubahan itu dilakukan melihat kepada aspek kemaslahatan yang akan ditimbulkan oleh tindakan tersebut. Pemberlakuan hilah sebetulnya bertujuan untuk memperluas hukum atau sebagai alternatif untuk keluar dari kesempitan aturan-aturan atau mencari solusi hukum 
yang masih dalam wilayah hukum syara' karena agama itu akan selalu memberikan kemudahan bukan mempersulit.

\section{Macam-Macam Hilah}

Allah Swt mewajibkan dan mengharamkan sesuatu, ada secara mutlak, ada yang terikat dengan syarat atau sebab tertentu. Shalat, puasa, haji, diwajibkan. Sementara zina, riba, membunuh dan sejenisnya diharamkan. Di samping itu, Allah juga mewajibkan dan mengharamkan sesuatu terikat dengan sebab-sebab tertentu seperti kewajiban kafarat disebabkan nazar dan keharaman memanfaatkan harta karena harta itu hasil curian. Dalam hal-hal tertentu Allah memberikan keringanan (rukshah) kepada orang tertentu karena ada hal yang menyulitkan. Bila ada suatu sebab yang menjadikan kewajiban sebagai sesuatu yang tidak lagi wajib; seperti shalat empat rakaat bagi musafir bisa menjadi dua rakaat dan melakukan safar agar dapat berbuka puasa. Melihat macam hilah yang dibolehkan dan yang tidak diboleh dapat dilihat dari macam-macam hilah.

Syaitibi (1971: 655) mengelompokkan hilah menjadi tiga kelompok:

1. Al-hilah yang disepakati tidak boleh, bila menyebabkan yang wajib tampak seperti tidak wajib atau yang haram tampak halal, seperti minum obat tidur saat masuk waktu shalat agar tidak shalat karena hilang akal disebabkan tertidur. Juga, menghibahkan sebagian harta agar tidak terkena kewajiban zakat.

2. Al-hilah yang disepakati kebolehannya dilakukan, bila untuk membela hak, mencegah kebatilan selamat dari haram dan menuju ke halal. Cara yang digunakan pun bisa yang dibolehkan bisa juga yang diharamkan hanya bila cara itu diharamkan, maka ia berdosa menggunakannya meskipun tujuannya tidak diharamkan. Dalam situasi perang, hal ini sangat diperlukan, karena perang adalah siasat. seperti pernyataan "kafir" dalam desakan dan ancaman keterpaksaan.

3. Al-hilah yang menjadi perdebatan kebolehan atau ketidakbolehannya. Hal ini disebabkan tidak adanya petunjuk yang pasti baik terkait dengan kelompok pertama ataupun kelompok kedua juga tidak ada penjelasan yang menyatakan bahwa ada maksud tertentu dari alsyāri' dalam hal itu atau ada hal yang bertentangan dengan maslahat.

Ali Hasballah (1971: 326) membagi hilah kepada:

1. Sebab-sebab syariah yang diciptakan untuk maksud tertentu bila dijalankan menurut garis syari'at. Misalnya, mengadakan perikatan jual beli sebagai sarana untuk memindahkan hak milik dan memanfaatkan barang yang diperjualbelikan, mengadakan ikatan perkawinan dengan maksud untuk menghalalkan hubungan kelamin dan mengadakan perjanjian-perjanjian yang lain.

2. Tindakan-tindakan yang pada dasarnya disyariatkan bila dimaksudkan untuk tujuan yang diciptakan untuknya atau digunakan untuk mencapai tujuan yang bukan diciptakan untuknya tetapi masih termasuk yang dibolehkan atau yang dituntut oleh syari'at.

3. Transaksi-transaksi yang pada dasarnya sesuai dengan syari'at akan tetapi dilakukan untuk mencapai sesuatu yang diharamkan. Transaksi seperti ini pada dasarnya menjadi tempat perbedaan 
pendapat di kalangan ulama. Misalnya, kasus orang yang menghibahkan sebagian hartanya menjelang haul dengan maksud untuk menghindari kewajiban zakat.

4. Akad yang pada dasarnya diharamkan bila dilakukan untuk mencapai sesuatu yang diharamkan. Misalnya, upaya untuk mentalak istri dengan menuduhnya bahwa ia telah murtad atau upaya untuk menghalangi istri dari menerima harta pusaka suaminya dengan memalsukan pengakuan suaminya bahwa ia telah ditalak tiga sewaktu suaminya dalam keadaan sadar. Hilah seperti ini tidak diperselisihkan oleh ulama tentang keharamannya.

5. Hilah yang diharamkan bila dilakukan untuk mencapai maksud yang hak seperti meminta kesaksian dua orang saksi palsu dengan tujuan agar orang yang mengingkari hutangnya mau membayar hutang tersebut.

Wahbah al-Zuhaily (1986: 912) membagi hilah kepada dua macam, yaitu:

1. Hilah yang dibolehkan; Perubahan hilah yang terjadi pada substansi hukum syar'i yang diletakkan untuk suatu persoalan tertentu dan digunakan dalam kondisi yang lain dengan tujuan untuk menetapkan kebenaran atau menolak kezaliman atau untuk mendapatkan kemudahan karena kebutuhan, hilah seperti ini tidak merusak atau tidak menghancurkan kemaslahatan syar'i. Misalnya, penduduk Bukhara menjadikan ijarah yang panjang sebagai suatu adat atau kebiasaan. Ijarah menurut Abu Hanifah tidak dibolehkan terhadap pepohonan, maka mereka terpaksa melakukan hilah dengan Bai' al-Wafa'. Bai' al-Wafa' merupakan hilah syar'iyyah yang dilakukan dengan sebab kebutuhan manusia untuk melepaskan diri dari kaidah yang melarang ijarah yang panjang terhadap pepohonan .

2. Hilah yang dilarang; Hilah yang bertujuan untuk merubah substansi hukum syar'i pada bentuk hukum lain dengan perbuatan yang sah menurut zahirnya, namun secara batin sia-sia. Seperti hilah yang objeknya menggugurkan hak syuf'ah dan mengkhususkan sebagian ahli waris untuk menerima wasiat dan untuk menggugurkan had pencurian. Hilah dalam bentuk seperti ini adalah hilah yang dilakukan untuk membatalkan hukum syar'i dengan praktek terselubung. Misalnya, seseorang menghibahkan hartanya di saat mendekati akhir perhitungan haul. Pada dasarnya tindakan seseorang menghibahkan hartanya adalah terpuji dan dianjurkan oleh syara', karena bertujuan untuk membantu sesama manusia dan termasuk perbuatan baik. Akan tetapi manakala menghibahkan harta menjelang masa haul datang yang pada saat itu si pemilik harta diwajibkan mengeluarkan zakat, ini merupakan suatu pelarian dari kewajiban zakat. Dengan adanya penghibahan harta, maka nisab zakat menjadi tidak tercapai dan akibatnya, orang itu tidak kena hukum wajib zakat.

Bila dicermati bentuk hilah yang dikemukakan oleh Wahbah al-Zuhaili di atas, maka dapat dipahami bahwa hilah hukum yang dibolehkan adalah perubahan terhadap substansi metode yang ditetapkan oleh syari'at Islam yang diletakkan untuk perkara tertentu dan digunakan dalam keadaan lain untuk mencapai suatu 
kebenaran menolak kezaliman atau memperoleh kemudahan. Sedangkan hilah hukum yang menyimpang adalah perubahan terhadap substansi hukum yang telah ditetapkan oleh syari'at menjadi hukum lain melalui suatu praktek yang benar secara lahir, namun salah secara batin.

Dari berbagai bentuk hilah yang dikemukan oleh para ulama di atas dapat dilihat bahwa pengklasifikasian tersebut disebabkan karena berbedanya sudut pandang ulama tersebut. Al-Syaitibi mengelompokkan hilah berdasarkan pengertiannya yang umum sedangkan Wahbah al Zuhaily membagi hilah berdasarkan kepada tujuan dilakukannya hilah. Dengan demikian pembagian hilah yang dikemukakan di atas, dapat dipadukan kepada tiga kelompok yaitu:

1. Hilah yang dibolehkan tujuannya bukanlah untuk membatalkan hukum syara' atau menghancurkan sendi maqashid al-syari'ah, tetapi bertujuan utnuk mencapai kebenaran menolak kezaliman dan mendapatkan kemudahan seperti mengucapkan kalimat kafir dalam keadaan terpaksa agar tidak terjadi pertumpahan darah.

2. Hilah yang dilarang, tujuannya untuk membatalkan hukum syar'i dengan praktek terselubung yang secara lahir diperkenankan oleh syara' namun terlarang secara batin atau hilah yang bertujuan untuk menghancurkan maqashid alsyari'ah dan menghilangkan kemaslahatan seperti nikah tahlil dan menghibahkan harta di saat kewajiban zakat sudah ada dengan maksud lari dari kewajiban syara'.

3. Hilah yang diperselisihkan hukumnya (antara boleh atau tidak) oleh para ulama sehingga menjadi lapangan ikhtilaf karena tidak adanya dalil qath'i dan wadh'i yang menjelaskan kebolehan dan larangannya. Seperti menggunakan saksi palsu untuk menagih hutang terhadap orang yang mengingkari hutang.

Mencermati pembahasan di atas, sangat tampak bahwa hilah syar'iyyah yang boleh dan yang tidak boleh sangat tergantung kepada perbuatan atau dampak yang dihasilkannya. Apabila kenyataan akhirnya bertentangan dengan prinsipprinsip syara' atau maslahat yang dituju syara', maka ia menjadi hilah yang tidak boleh dilakukan. Akan tetapi, bila sebaliknya, kenyataan akhirnya tidak bertentangan dengan prinsip-prinsip syara' bahkan dengan hilah akan dapat mencapai maslahat yang dituju dalam syara' maka ia menjadi hilah yang dibolehkan.

\section{Hasil Penelitian tentang Penerapan Hilah dalam Fatwa DSN}

Hilah hanya salah satu dari banyak cara yang dapat digunakan untuk menemukan hukum dan mengembangkan berbagai masalah. Hilah syariyah sebagai upaya dalam mewujudkan maqashid al-syari'ah juga pernah terjadi pada masa-masa umat dahulu, seperti pada kasus yang terjadi kepada Nabi Ayub yang telah penulis uraikan pada pembahasan sebelumnya, nampak jelas bahwa hilah berfungsi untuk mencapai kemaslahatan. Maslahat yang ditimbulkannya adalah istri Nabi Ayub tidak merasakan sakitnya hukuman dari sumpah yang telah diucapkan oleh Nabi Ayub. Hal ini akan menjaga dan menyelamatkan jiwanya dari siksaan. Menjaga keselamatan jiwa dalam maqashid al-syari'ah adalah upaya yang dilakukan 
dalam rangka memelihara jiwa yang termasuk kepada tingkatan dharuri.

Kisah yang pernah terjadi kepada Nabi Yusuf, hal ini adalah hilah yang dipakai oleh Nabi Yusuf supaya saudaranya bisa tinggal bersamanya. Dalam hal ini, Nabi Yusuf dapat hidup bersamaan dengan saudaranya tersebut, meskipun hukuman akan tetap dijalankannya. Beberapa praktek hilah di atas, menunjukkan bahwa hilah bertujuan menghilangkan kesulitan dan mengambil kemudahan dalam menyelesaikan suatu pesoalan dan memperoleh kelapangan serta dalam rangka menciptakan kemaslahatan.

Penerapan hilah dalam kalangan Hanafiyah tertumpu kepada hilah yang dapat merealisasikan kemaslahatan kepada umat ketika mengalami kesulitan dalam menghadapi persoalan hukum. Pandangan Hanafiyah, maslahat dalam penetapan sebuah hukum harus dikedepankan karena hal itu sejalan dengan tujuan syari' dalam menciptakan hukum. Maslahat menurut mereka juga dapat men-takhsis aturan-aturan yang menimbulkan kesukaran dan kesempitan, misalnya tindak kriminal yang terjadi dalam kamar mandi perempuan, fuqaha' Mazhab Hanafi menerima kesaksian perempuan. Oleh sebab itu, mereka telah men-takhsis nash-nash Alquran dan Sunnah dalam masalah kesaksian, di mana Alquran dan Sunnah mensyaratkan bahwa saksi itu harus laki-laki atau laki-laki dan perempuan.

Takhsis ini berdasarkan tuntutan maslahat karena tanpa keberadaannya akan dapat menyia-nyiakan hak-hak perempuan. Pemeliharaan terhadap hak merupakan maslahat syar'iyah yang dharuriyat (primer). Merealisasikan maslahat dalam pandangan Hanafiyah sangat penting, sebab tujuan syari'at adalah menghendaki kemaslahatan bagi umat. Oleh sebab itu, setiap peristiwa hukum yang terjadi, untuk merealisasikan hukumnya dalam pandangan Hanafiyah maslahat perlu diperhatikan, hilah adalah salah satu kaidah yang dijadikan sebagai sebuah metode untuk menciptakan maslahat tersebut. Fatwa Dewan Syariah Nasional yang dianalisis dalam penelitian ada 8 fatwah:

1. Fatwa Dewan Syariah Nasional Nomor: 22/DSN-MUI/III/2002 tentang Jual Beli Istishna' Paralel

2. Fatwa Dewan Syariah Nasional Nomor: 31/DSN-MUI/VI/2002 tentang Pengalihan Utang

3. Fatwa Dewan Syariah Nasional Nomor 27/DSN-MUI/III/2002 tentang al-ljarah alMuntahiyah bi al- Tamlik

4. Fatwa Dewan Syariah Nasional Nomor 42/DSN-MUI/ V/ 2004 tentang Syariah Char Card

5. Fatwa Dewan Syariah Nasional Nomor 44/DSN-MUI/ VIII/ 2004 tentang Pembiayaan Multi Jasa

6. Fatwa Dewan Syariah Nasional No: 50/DSN-MUI/III/ 2006 tentang Akad Mudharabah Musytarakah

7. Fatwa Dewan Syariah Nasional Nomor 72/DSN-MUI/ VI/ 2008 tentang Surat Berharga Syariah Negara Ijarah Sale and Lease Back

8. Fatwa Dewan Syariah Nasional Nomor 73/DSN-MUI/XI/2008 tentang Musyarakah Mutanaqisah

Fatwa DSN yang dianalisis di atas, ditemukan banyak yang memakai akad ganda atau multi akad dalam satu fatwa. Bila dikaitkan dengan Hadis yang melarang akad ganda/multi akad dalam satu objek akad, maka di sini dapat dikatakan fatwa 
DSN tidak menghiraukan Hadis ini walaupun dalam dasar hukum ditulis. Tetapi bila diamati secara mendalam ketentuan fatwa yang ditetapkan, kelihatan ulama yang menetapkan fatwa ini mensiasati ketentuan fatwa tidak bertentangan dengan nash yang ada yang berkaitan dengan masalah yang ditetapkan.

Menganalisis penerapan hilah dalam fatwa Dewan Syariah Nasional sebagaimana yang telah dipaparkan di atas, dapat dipahami bahwa delapan fatwa yang dianalisis umumnya memakai metode hilah yang mendasarkan pendapatnya terhadap menyahuti kebutuhan masyarakat dalam mewujudkan maslahat sebagaimana yang disebutkan dalam Fatwa Nomor 31,nomor 42, Nomor 44, Nomor 72 dan Nomor 73. Fatwa Nomor 22 dan 27 ditetapkan dalam pertimbangan berdasarkan kebiasaan yang dipraktekan masyarakat, dapat dikatakan berdasarkan 'urf. Sedangkan fatwa Nomor 50 ditetapkan berdasarkan akad yang diboleh dalam fikih secara terpisah yaitu akad mudharabah dan akad musyarakah, kemudian dua akad ini digabungkan menjadi satu objek yang disebut dengan akad mudharabah musytarakah. Hal seperti inilah dapat dikatakan fatwa ini ditetapkan berdasarkan metode hilah yang mencari hal-hal yang tidak melanggar apa yang telah ditetapkan secara umum dalam bermuamalah.

Fatwa DSN dalam penetapan akadakad produk perbankan syariah diperkirakan terjadi modifikasi fikih muamalah. Dalam proses penetapan fatwa sebagaimana yang disebutkan di atas dapat dikatakan memakai metode hilah dengan cara memodifikasi dan mengakali format fikih muamalah. Dan pemakaian hilah dalam menetapkan fatwa DSN dapat dibenarkan atau tidak bertentangan dengan apa yang telah ditetapkan oleh nushus sesuai dengan pendapat yang dikemukakan oleh Wahbah al-Zuhaili bahwa perubahan hilah yang terjadi pada substansi hukum syar'i yang diletakkan untuk suatu persoalan tertentu Wahbah al-Zuhaily, 1986: 912 ) dan digunakan dalam kondisi yang lain dengan tujuan untuk menetapkan kebenaran atau menolak kezaliman atau untuk mendapatkan kemudahan karena kebutuhan, hilah seperti ini tidak merusak atau tidak menghancuran kemaslahatan syar'i Wahbah al-Zuhaily, 1986: 912) Hilah seperti ini dibolehkan berdasarkan syar'i karena hilah ini bukanlah bertujuan membatalkan hukum syar'i atau melepaskan diri dari kewajiban yang ditanggung oleh seseorang, tapi adalah sebagai solusi atau cara untuk keluar dari kesempitan sebagaimana yang dilakukan oleh DSN dalam menetapkan fatwa yang telah dijelaskan di atas.

Mencermati pembahasan di atas, sangat tampak bahwa hilah syar'iyyah yang boleh dan yang tidak boleh sangat tergantung kepada perbuatan atau dampak yang dihasilkannya. Apabila kenyataan akhirnya bertentangan dengan prinsip-prinsip syara' atau maslahat yang dituju syara', maka ia menjadi hilah yang tidak boleh dilakukan. Akan tetapi, bila sebaliknya, kenyataan akhirnya tidak bertentangan dengan prinsip-prinsip syara' bahkan dengan hilah akan dapat mencapai maslahat yang dituju dalam syara' maka ia menjadi hilah yang dibolehkan.

Hasil penelitian ini diharapkan dapat digunakan pertama secara akademik dapat memperkaya khazanah intelektual hukum Islam, terutama di bidang ekonomi syariah. Fokus penelitian ini membahas tentang fatwa DSN yang 
memiliki keunggulan di satu sisi fatwa merupakan upaya ulama dalam mengantisipasi tuntutan atau kebutuhan masyarakat pada zamannya, oleh karenanya fatwa lebih memiliki relevansi sosial dalam aplikasinya dibandingkan dengan bidang fikih lainnya. Sedangkan di sisi lainnya fatwa mengambarkan interaksi kreatif ulama antara ajaran yang baku berdasarkan nash dengan perkembangan dan tuntutan zaman. Kedua secara sosial hasil penelitian ini diharapkan berguna bagi masyarakat berupa penguatan dari fatwa DSN dan sekaligus bahan evaluasi bagi stakeholder perbankan syariah dan masyarakat yang konsen terhadap ekonomi syariah.

\section{PENUTUP}

\section{Kesimpulan}

Proses penetapan fatwa DSN sebagaimana yang dibahas dalam penelitian ini dapat dikatakan memakai metode hilah dengan cara memodivikasi dan mengakali format fikih muamalah. Dan pemakaian hilah dalam menetapkan fatwa DSN dapat dibenarkan atau tidak bertentangan dengan apa yang telah ditetapkan oleh nushus. Praktek hilah dalam penetapan fatwa DSN menunjukkan bahwa hilah yang diterapkan bertujuan menghilangkan kesulitan dan mengambil kemudahan dalam menyelesaikan suatu pesoalan dan memperoleh kelapangan untuk mewujudkan kemaslahatan dalam masyarakat.

\section{Saran}

1. Perbankan syariah dalam melayani masyarakat hendaklah melakukan akad kepada nasabah secara transparan dan nasabah diberikan lembaran akad yang telah disepakati antara bank dengan nasabah

2. Disarankan kepada masyarakat yang bertransaksi dengan perbankan syariah membaca terlebih dahulu fatwa DSN yang berhubungan dengan akad yang dilakukannya dengan bank, dan nasabah ikut mengawasi apakah bank konsisten menjalankan ketentuan dalam fatwa DSN tersebut.

\section{DAFTAR KEPUSTAKAAN}

Abu Zahrah, Muhammad, Ushul al-Figh, Mesi: Dar al- Arabi,tt.

Al Syatibi. t.th. al Muwafakat fi Ushul al Al syari'ah, Beirut: Dar al-Kitab alIlmiah.

Al-Kahlani, t.th. Subu al-Salam, Bandung: Dahlan.

al-Suyuthi, Jalaluddin Abdurrahman. t.th. al-Assyba'wa al-Nadhoir, Syirkah $\mathrm{Nu}$ asia.

Bakr bin Abdullah Abu Zaid, Ibnu Qyyim al-Jauziyah, Hayatuhu wa Atsruhu, Riyadh: Dar al- Hilal lil, 1980.

Bukhari, Muhammad bin Ismail, Shahiah al-Bukhari, Beirut: Dar al-Shuub, tt.

Dahlan, Abdul Aziz. 1996. Ensiklopedi Hukum Islam, Jakarta: Ichtiar Baru van Hoeve.

Firdaus, Muhammad. 2005. Ekonomi Syariah Kontemporer, Jakarta: Renaisan.

Hasballah, Ali. 1971. Ushul al-al-Tasyri; alIslami, Mesir: Dar al- Ma'arif.

Jauziyah, Ibn Qayyim. t.th. I'lam alMuwaqqi'i 'an Rab al-'Alamin, Kairo: Maktabah Ibn Taimiyyah. 
Karim, Adiwarman. 2003. Bank Islam Analisis figh dan Keuangan, Jakarta: IIIT.

Mubarok, Jaih, 2004. Perkembangan Fatwa Ekonomi Syariah di Indonesia, Bandung: Pustaka Bani Quraisy.

Qardhawi, Yusuf, 2001. Bunga Bank Haram, Jakarta: Akbar Media Eka Sarana.

Qawanin, Ibnu Juzayy al, 2005. Al- fiqhiyah, Tahqiq Abdullah al- Minsyawi, Kairo: Dar al- Hadits.

Shihab, M. Quraish. 2002. Tafsir al-Misbah, Jakarta: Lentera Hati.
Syafthibi, 1971. al-Muwāafagāt fi Ushul alSyarīah, Beirut: Dar-al-Khitab alIlmiah.

Syarbani. 2000. Muhammad Khatib, Mungni alMuhtaj Ila Ma'rifah Ma'ani Alfazh alMinhaj, Beirut: Dar al-Kutub alIlmiyah.

Syarifuddin, Amir, 1999. Ushul Figh, Jakarta: Logos Wacana Ilmu.

Syarqa', Mustafa Ahmad, Syarah al-Qanun as-suri al-Uqud al-Musammah, Damaskus: Dar al-Kitab 1998.

Syaukani, t.th. Irsyad al-Fuhul, Beirut, Dar al-fikr. 